\title{
THE DISAPPEARED LITURGICAL RANK - OIL CONSECRATION FOR DEAD, ACCORDING TO LITURGICAL COLLECTION NO. 64 (XV - XVII C.), KEPT IN THE SCIENTIFIC ARCHIVE OF BAS
}

\author{
Galya Gospodinova \\ gachebg@abv.bg
}

Scientific Archive at the Bulgarian Academy of Sciences, Sofia, Bulgaria

\begin{abstract}
In the 15th - 16th centuries, the so-called oil lighting for the deceased was carried out. This missing liturgical rank is kept in liturgical collection No. 64 (XV - XVII c.), stored in the Scientific archive - BAS. Tracking it will give an idea of how this oil lighting was done. Liturgical Collection No. 64 is the earliest transcript, which stores the entire sequence.
\end{abstract}

Complaint

Keywords: Anointment; Deceased; Ritual; Collection;

\section{ИЗЧЕЗНААИЯТ ЧИН - МАСАОСВЕТ ЗА ПОКОЙНИК СПОРЕА БОГОСАУЖЕБЕН СБОРНИК № 64 (XV - XVII В.), \\ СЪХРАНЯВАН В НА - БАН}

Га^я ГоспоАинова

Научен архив на Българска акалемия на науките, Софияя, Бьлгария

Резюме: През XV - XVI в. е извършван т. нар. Маслосвет за покойник. Това изчезнало последование е съхранено в Богослужебен сборник № 64 (XV - XVII в.), съхраняван в НА - БАН. Проследяването на чина ще дале представа за това как е извършван този маслосвет. Богослужебен сборник № 64 е най ранният препис, който съхранява цялото последование.

оплакване.

КАючови Ауми: маслосвет; покойник; ритуал; сборник;

Аанните, с които разполагаме от библейските текстове се отнасят до това - какви са местата за погребване, поведението спрямо покойниците - чужАенци, начините за приготвяне на тялото на покойника и Аьржането на близките слеА загубата на техен човек. СпореА Свещеното Писание местата, в който са извьршвани погребения са: гробниците (Бит. 23:6), пещерите, нивите (Бит. 23: 20); (Бит. 49: 30-31); пол Аьба (Бит. 35:8), край 
Пьтя (Бит. 35:19); (Бит. 48:7); в Аьлбочината на ямата (Езек. 32: 23); в бащиния гроб (СьА. 8: 32); (СьА. 16: 31) ; (2 Цар. 2: 32); в гралината (4 Цар. 21: 26) и изсечен в скала (Исая 22: 16); (Мат. 27: 60) и мр.

Помазване с масло се е извьршвало по различни повоАи в старозаветен и новозаветен план - част от ритуал за признаване и утвържАаване на върховен цар (ЗЦар. 1: 34); когато нещо се осветява (Изх. 28:41); (Изх. 30: 25-30); (Изх. 40: 9-15) (Аев. 8: 10); признак за святост (Пс. 89: 20); при болест (Яков 5: 14); помазване на тялото за погребение (Марк 14:8); (Йоан 12: 3-7), а за праведните и мъдрите „миро да не Аипсва от главите им" (Ек^ес. 9:8). От Аруга страна светото миро се забранява за "човешката пльт", то е предназначено само за свещенодействащите - Аарон и синовете му (Изх. 30:32); забранява се също помазване при предаване на гибел (Михей 6: 15).

В старозаветна епоха съществували забрани, които се отнасят за погребване на покойниците. Пример за това е Авраам, когато се представи^ за пришьлец и поискал място от хатейците, за Аа погребе Сара (Бит. 23:4). Пришьлците и заселниците (чужАоземците) са смятани за чужАенци, който трябвало Аа бъАат погребвани в отлелни гробища.

Според думите отправени към Юлейския цар се вижАа, че погребването на нечестивците също трябва да бъле отлелено от останалите (Ерем. 22: 19). ПоА покойници - "чужАенци", са смятани и обесените ' какъвто е примера с ЮАа Искариот. Той се разкаял слеА предателската си постьпка и отнел живота си чрез обесване. С цената на крьвтта от тридесетте сребърника е закупена грънчарева нива (спореА предреченото от Еремия), в която $\Delta а$ се погребват чужАенци (Мат 27: 5-7). Практиката свьрзана със загуба на близък човек спореА библейските текстове е „порязвания по месата" (Аев. 19: 28) и „брьснене межАу очите" (Второзак. 14: 1). Ако някой се Аопре Ао мъртво тяло е смятан за нечист в продьлжение на седем Ани (Числ. 19: 11-13); (Второзак. 26: 14). Има прави^о за близките на починалия, относно т. нар. "Ааване за мьртвец" - $\Delta а$

1 В Стария Завет обесените, са били смятани за проклети от Бога - "Ако някой извърши престьпение, което заслужава смърт, и бъде умъртвен като го обесиш

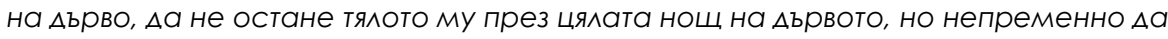
го погребеш в същия Аен, защото обесеният е проклет от Бога, така $А$ не оскверниш земята, която Господ твоят Бог ти Аава в наслеАство". Втор. 21: 22 - 23). 
бъАе чисто и придобито по честен начин (Второзак. 26: 14). Полобно разбиране за чистота имат първите християни и за тялото на починалия. Подготовката му изисквала Аа бъде измито и чисто (Аеян. 9: 36), а очите му били затваряни с рьце (Бит. 46: 4), като го целували (Бит. 50 :1), балсамирали (Бит. 50 : 2), (Бит. 50 : 26) и оплаквали с т. нар. нарежАания (3 Цар. 13: 30), (3 Цар. 14: 13). Новозаветните текстове свелетелстват за последните Ани преди Възкресението на Иисус и показват, че Той предрекъ^ Своята полготовка за погребение чрез излятото миро върху неговото тяло (Мат 26: 12). Ев. Матей $а$ ава сведение, че тялото на Христос е обвито в "чиста плащаница" (Мат. 27: 59), а спореА ев. Йоан, плащаницата е с ароматите спореА юлейските обичай (Йоан 19: 40).

Най - ранните свеления за ритуали извършвани нал починалите е от ерата на палеолита когато костите на починали са оцветявани с червена боя и са реконструирани с помощта на варовикова паста (Shivarov, 2011 : р. 15), (Shivarov, 1992). Оп^акването на мъртвеца в гръцката античност е утвьрлен ритуа^ (Petkanova, 2011: р. 45). Открити са т. нар. "сльзници”, които са предназначени, за да се пьлнят сьс сьлзи - материално Аоказателство за любовта и скръбта (Petkanova, 2011: р. 45). Всички тези акценти Аават преАстава каква е старозавентата и новозаветната практика свързана с погребалните обреди. Постановленията от Картагенския поместен събор (419 г.) и Шестия Вселенски събор изАават практиките свързани с покойника, които са при^агани Ао времето на провежАането им т. е. $\triangle О$ V-VII в. Картагенският събор (419 г.) Аава свиАетелства за покойника, които засягат богослужебната Аисциплина. ЕАни от найважните забрани са: $\triangle$ а не се $а$ ава свето причастие на умрели и $\Delta а$ не крьщават вече починали².

Същата забрана отнасяща се Ао причастието се сьльржа и в Прави^о 83 на Шестия Вселенски събор (680/681г.)³. От тези постановления

2 Картагенски поместен събор, Правило 26, гласи: Постановено е $А$ а не се $а$ ава свето причастие на умрели, понеже е написано: "вземете, яжте" (Мат. 26:26), а пьк телата на мъртви не могат нито да взимат, нито да ядат. Така също презвитери, поради незнание, да не кръщават вече починали.

3 Прави^о 83 гласи: "Никой $а$ не Аава свето причастие на тела на умрели, понеже е писано: „Вземете яжте” (Мат. 26:26), а телата на мъртви не могат нито Аа взимат, нито Аа яАат. 
може $\Delta а$ заключим, че най- вероятно са принасяли светите дарове за починали, защото погребалните обрели през пьрвите християнски векове са свързани с митургията (Avxentii, 2006: р. 446). Аипсата на самостоятелност на чинопоследованието определя молитвите, които са вкАючени в него Аа са вероятно изричани по време на заупокойни Аитургии (Milosevic, 2011). Прави^о 50 от Картагенския събор, потвържАава тази практика и определя:

„Светите дарове $\Delta$ а се пренасят само от неяли ... А ако се извьршва вечерно време поменаване на някои епископи или на други починали, тогава да се четат само молитви, ако се окаже, че ония, които я извършват, са обялвали." 4 От схолията на антиох. Патриарх Теолор Ва^самон отнасяща се ло правило № 83 на Трулския събор, научаваме, за практика, която се е извършва с починал архиерей: „А че на архиереите, полир смъртта [им], турят в ръце свети хляб и тъй ги погребват мисля, че е за прогонване на злите духове и са да бъле напьтствуван с него към небесата удостоеният с великото и апостолско обетование." (Tsankov, Stefanov and Tsanev, 1913: 338) Картагенският събор се постановява, че ако епископ умре и остави за свои наследници еретици или езичници, е анатема, а името му да не се споменава от Божиите свещеницй ${ }^{5}$. Аруго прави^о № 140 от същия поместен събор опрелеля - ако епископ облече в монашеско облекло девица, за $л а$ запази девическото целомьдрие, то

4 Картагенски поместен събор, Правило 50, гласи: "Светите Аарове $а$ с се пренасят само от неяли. ИзкАючение става в еАин Аен на Годината, в който се извършва Господнята вечеря. А ако се извьршва вечерно време поменаване на някои епископи или на Аруги починали, тогава $\Delta$ а се четат само молитви, ако се окаже, че ония, които я извършват, са обядвали."

5 Правило 92 гласи: „ОпреАелено е и следното, че ако някой епископ преАпочете преА църквата еретици или езичници, били те негови сродници или не, и ги остави за свои наслеАници, такъв епископ и когато умре, Аa е анатема и името му $А$ व

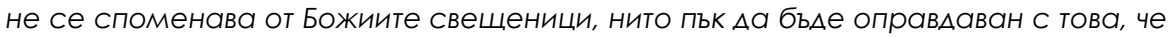
е умрял без завещание, защото, щом е бил поставен за епископ, трябвало е веднага да се разпореди с имуществото си по закона и както прилича на званието му." 
този епископ не поллежи на никакво осъжданеб. СпореА народните обичай, когато почине някой, то Арехите му се свалят и той се облича с нови дрехи. СлеА това се обрьща с главата на запал и се покрива с бяло

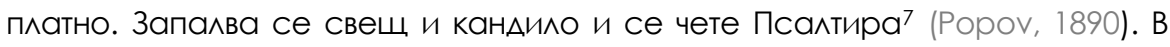
Православната цьрква погребението се смята за обреА. В ИзточнатаСирийска цьрква, то е еАно от светите тайнства на цьрквата. Във всички религии, ако покойник не се погребе се смята за безчестие (Avxentii, 2006: p. 67).

Нетленните останки на починалия християнин се смята като признак на святост. Съществува обичай в някой манастири, при които слеА определен периол от погребване се е изкопавал гробът и ако тялото на починалия монах е изтляло, то се смята като белег за неправеден живот. Като условие за канонизация е наличието на приятен аромат от останките на починалияв. Редьт опрелелен за погребение в Православната цьрква винаги се смесва с местни практики и езически обичаи.

Например, чупене на чинияс вода слеА изнасяне на покойника от АОмът му; изнасяне на жалейки и дарове навън през нощта когато е погребението; поставяне на монети в устата му (или на челото му); поставяне на ястия и подаръци при ковчега (Petkanova, 201 1: 49), „окачване на коси от страна на жените и Аевойките в знак на скрьб” и т. н. (Petkanova, 2011: 49). Съществува практика, която не се извършва наА починал свещеник. Свързва се с поставяне на лента на челото на покойника с

6 Правило 14 гласи: "Постановява се също така, че ако някой епископ облече в монашеско облекло, или е облякъл вече, цевица, която още не е навършила

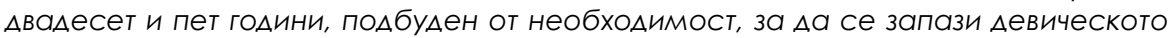
целомьдрие, застрашавано от опасност, било че има полозрение за някой ^юбящ я, който има в^аст, било че някой иска Аа я отвлече, или пьк тя самата е била сломена от някаква смъртоносна опасност, или най-сетне епископът е извършил това по молба на нейните родители или на наставниците иे, за да не би

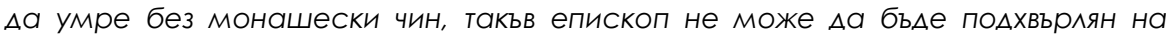
никакво осъжАане от съборното постановление, което опреАеля горната възраст за обличане в монашеска дреха."

7 Попов, Ив. Тжжачки (оплаквания на мъртввци).В: СбНУ, Кн. 2, с. 64 - 65, се съобщава, че в Крушево е имало обичай, когато се получи скрьбна вест за някой, който е починал в чужбина, то дрехите му се простират и нал тях се „нарежАа" (Popov, 1890).

8 Вж: Canonization / Канонизация [http://www.pravenc.ru/text/1470233.html, (Last view: 01.09.2019)] 
изображение на Иисус Христос, Божията Майка и Йоан Богослов (обикновено с налпис (,Трисветое"), след измиването му, асоциирайки се по този начин с венеца, с който трябва $а$ се увенчае главата на християнина в Царството небесно?.

Богослужебен сборник № 64 сьхранява изчезналото последование наречено "Маслосвет" за покойник. Той е от XV - XVII век и се съхранява в сбирка X от НА - БАН. Първата част от този препис (А. 1- 208) спореА съдьржанието си е Требник. Водните знаци, които са открити в тази част на преписа: сърце в крьг (№ 4310 от 1400 г. ), полуносорог (№ 9936 от 1403 г.) и ^ък със стре^а (№ 792 от 1406) (Kodov, 1969: р. 107), отнасят паметника към най - ранния периол от появата на чина т. е. 1400 - 1406 г.

С Аруги Ауми, това е и най-старият препис, който сьхранява изчезналото последование 10 . Тази част на рькописа е писан сьс среден полуУстав С реАки уАарения И наАреАни знаци. Заглавията са писани С везано писмо и червенослов. В Сборник №64, последованието е поместено слеА чина на маслосвет (елеосвещение) извьршван от 7 свещеника. То обхваща листовете 62a-87a.

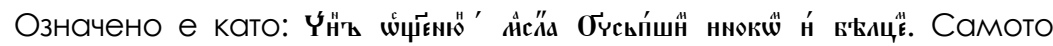
заглавие определя, че маслосветьт е за иноци т. е. монаси и т. нар. белци т. е. светски човек. В послеАованието са включени слеАните елементи: Бі⿱宀㠯.

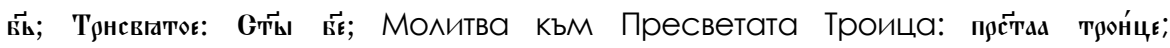

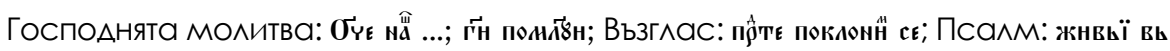
поночь

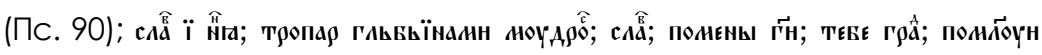
мє; Канон гАас 2 с песни от 1 Ао 6 глас и ирмоси (^. $626-65 a)$; слава -

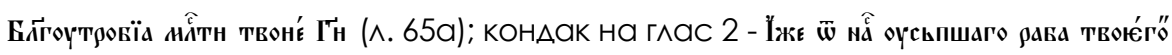

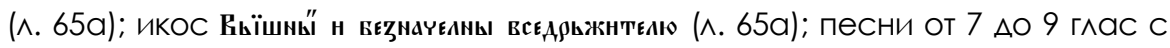
ирмоси и слави; нататьк са стихири на св. Теофан глас. 1 - подобен:

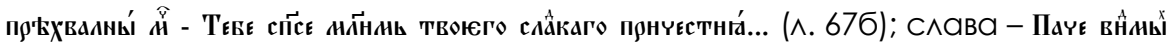

9 Вж: Wreath / Венчик [http://www.pravenc.ru/text/150357.html, (Last view: 01.09.2019)]

10 Това е най- стария препис, който съхранява и още едно изчезнало последование водоосвещаване на нов месец, съдьржащ се на л. 9а - 20 б. 


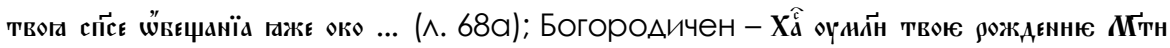

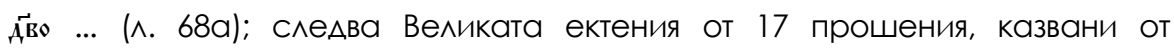
Свещеника или Аякона; възгАаС: ІЯ̆ко ты юсн вьскёсєнїв н́ жнвоть н́ покон ... (А. 69б); слеАва прокимен гАас 1, казван от пьрвия Свещеник, - Ӓша ю́гг вы Ёагы

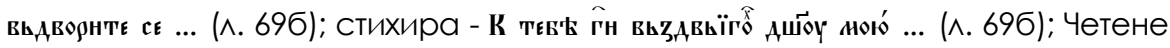

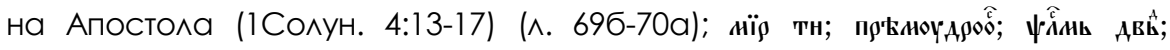

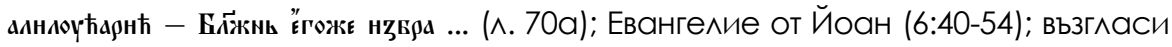

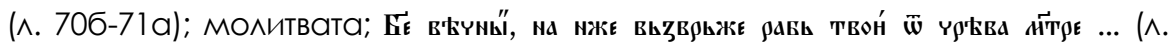
71а-72б). Между тази и следващата молитва има възглас: ІІ̆кю ты" ю́сн

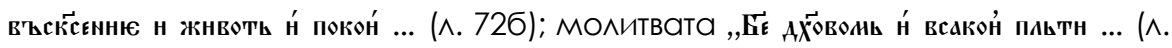

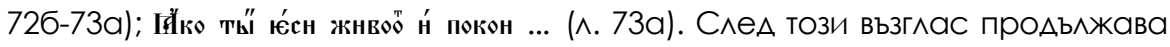

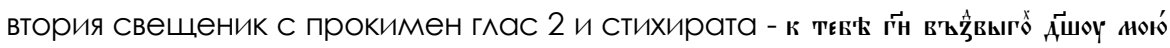
(^. 73a); слеАва четене от 1Кор. 15: 20-28 (^. 73a-73б); ПреАи евангелското

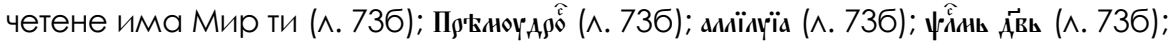
амиїуїа (^. 73б); вйжєнь '́го же н́zвра (^. 73б); Евангелие на Йоан 6:48-54 (^. 73б-

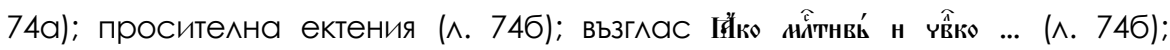

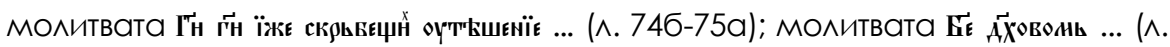
75а); третия свещеник казва прокимен глас 3 - Даша ю́го вы вйгы выддвонт ск ...

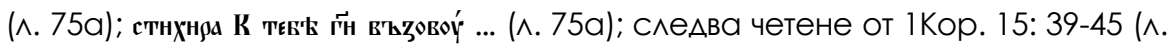
75a-756);

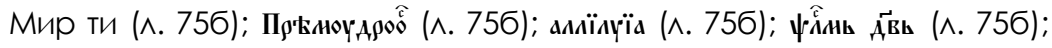
а^^ ^^у а (^. 756); Евангелие от Йоан 6: 35-39 (^. 756-76а); просителна ектения

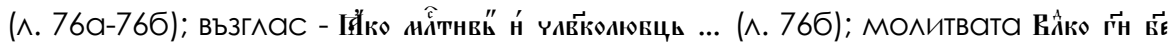

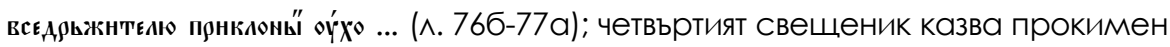
гАас 4 - Ашша юге вь вӓгы

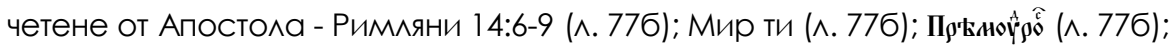

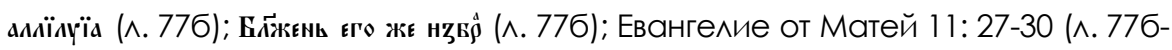
78a); просителна ектения (^. 78a); възглас (^. 78a); молитва БЕ $\overrightarrow{\mathbf{E \varepsilon}}$

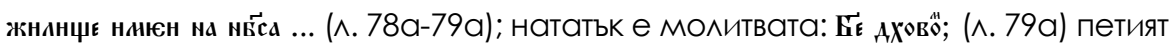
свещеник казва прокимен гАас 5 - Аша юго вы вагы 
въzовоү ... (^. 79а); следва четене от Апостола 1 Кор. 15: $47-57$ (^. 79а-80а);

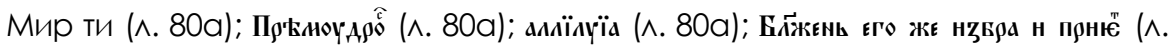
80а); Евангелие от Йоан 5: 17-24 (^. 80а-80б); просителна ектения (^.80б-81 а);

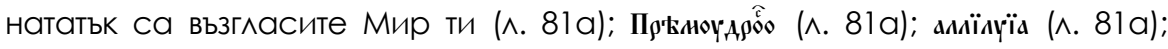

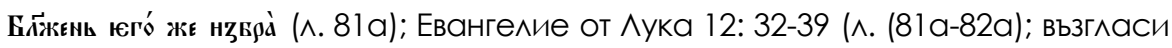

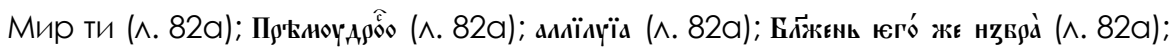
Евангелие от Йоан 5:24-30 (^. 82а-82б); слеАва просителна ектения (^. 82б-

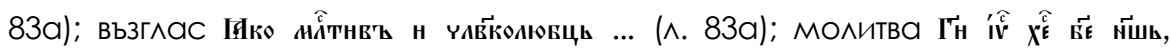

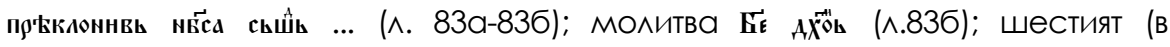
рькописа е означен като седми) свещеник казва прокимен глас 7 діша юго

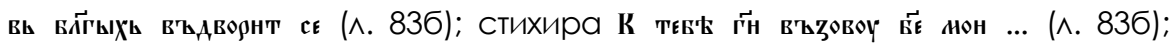

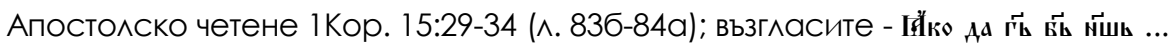

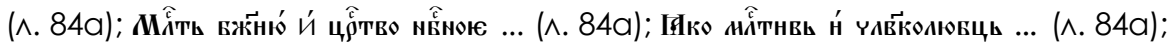

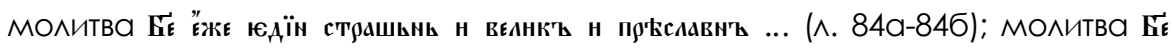
Аүовӧ ... (^. 84б); сеАмият (това е всъщност шестия) свещеник казва

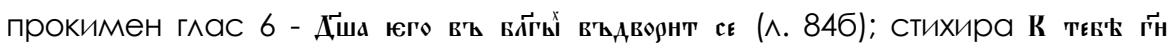
възовоү ... (^. 84б); Апостолско четене 1Кор. 15:12-17 (^. 84б); (тук ^ипсва ^ист, който сьдьржа продьлжението на четенето, а също и часта от Евангелското четене.

На следващия ^. 85а се вижАа че Евангелието е от Аука 12: 38-40);

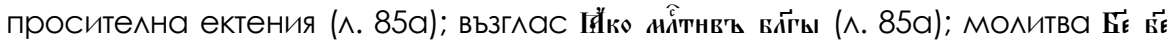

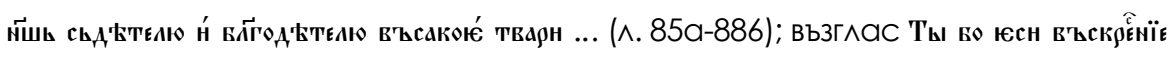

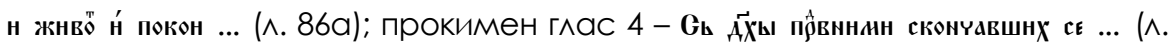
86б); Вь поконцн твоюмь г̈н (А. 86б); слава Тьї иї юсн Б́'́ сьшьдый вь а́ды (^. 86б);

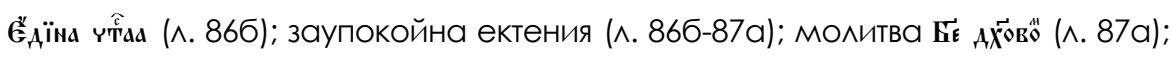

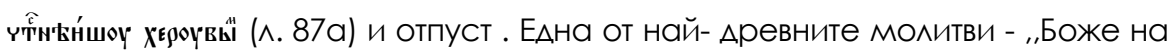
Ауховете и на всяка пльт..." в това послеАОвание е използвана от всичките седем свещеници, с изкґючение на шестия, който е поставен в ръкописа пол № 7. Това не бива $а$ а се смята за някаква специфика в последованието, а по - скоро е породено от обърканите миста при реставрационната полредба. Така седмият свещеник- участник в чина е 
поставен пол №6, ^. 83б, а мястото му трябва $\Delta а$ е на ^. 84б. Циоровото означаване с червенослов ясно определя това. Аистовете са объркани

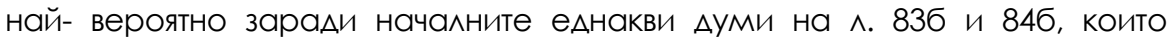
започват с „воу твююмюу". Така молитвата „Боже на духовете и на всяка п^ьт..." е произнасяна в края на часта отслужвана от еАиния свещеник и преди началото на прокимена изказван от следващия. Наблюдава се, че частите на всеки еАин от 7 - те свещеници образуват еАно малко чинопослелование, което от своя страна включва елементите: прокимен (на съответния глас), стихира, апостолско четиво, възгласи, евангелско четиво, просителна ектения, молитва и накрая молитвата: „Боже на духовете и на всяка пльт...". Евангелските четива използвани в т. нар. Маслосвет наА покойник са от Йоан, Матей и Аука, а използваните апостолски четива са от 1Коринтяни, Риммяни и 1Солунци. В препис № 64 на ^. 846 се съАьржа част от 1Кор. 15:12-17, слеА този лист трябва да има още, защото слеАващия ^. 85а продьлжава с евангелието от Аука 12: 38-40 т. е. апостолското и евангелското четиво са сляти - пьрвия без край, а втория без начало. Така и^и иначе се открива какви са били частите от Св. Писание използвани в чинопоследованието. Според елементите включени в състава на чина, отслужван от всеки свещеник (изброени по-горе) може да определим, че при шестия и сеАмия свещеник Аипсват евангелските четива, просителната ектения (при седмия - ^. 83б-84а) и възгласите (при шестия - ^. 846-85а).

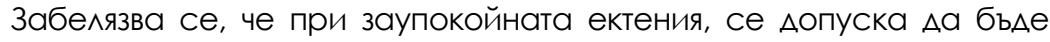
произнасяна от Аякона или от свещеника. Това богато послеАование, в следствие на усложнения си състав не е издьржало на промените настьпили в богослужението. Най - вероятно с намаляване състава на служещите е изгубен смисъльт вложен в този маслосвет. Елементите Използвани от всеки еАин Участник в послеАованието се откриват в Аруги обреди и свещенолействия. От друга страна е правена разлика при осветеният елей в това последование и този използван при болен. При вторият - елеят има озАравителни свойства. Като Аруга причина за отпалане на този чин може $а$ а се посочи, че важна роля изиграват заимстването на част от елементите му от Аруги обреди като: погребение на възрастен, на дете, опело на свещеник, монах, мирянин, панихида и т. н. Остава $\Delta а$ посочим - как е би^ помазан покойника. Този въпрос в ръкопис № 64 остава 
неопределен, защото няма рубрика, която да посочва Аействията С осветения елей. Най - вероятно е извьршено преди спускането в гроба, а остатькь изсипвали върху гроба му (крьстообразно). като отражение на тази практика откриваме в съвременния Требник, кълето в последованието „Погребение на възрастен" е записано сленното: „СлеА отпуста тялото се слага в гроба и прели да бъле покрито, свещенникът взима с прьст, изсипва я накрьст наА тялото и казва „ГоспоАня е земята и онова що я изпьлня"... Сетне излива наА тялото накрьст елей от канАилото, или изсипва пепел от кандилницата" (Ordinary book, 2002: р. 272).

При погребението на дете се откриват същите действия (Ordinary book, 2002: р. 298). Причините за установяване на маслосвет наА покойник като чинопоследование се крие както в старозаветната така и новозаветната традиция. Всичко това влияе на монашеските братства, които най- вероятно са въвели в употреба това чинопоследование. Отслабване влиянието на монашеските общности е елна от причините за прекратяване използването на този маслосвет. Можем да определим, че маслосвет за покойник е бил отслужван през периола от началото на 1400 Ао 1806 г. т. е. Ао времето, когато св. Софроний Врачански написва своето Поучително евангелие.

Епископьт на Враца Аава еАно от послеАните свилетелства за извършване на маслосвет наА покойник (Vrachanski, 1856). В своите неделни проповеди Св. Софрроний полчертава: „Нали гледаме как изпровождаме мъртвите с молитви и песни, с туй показваме на Бога благодарение, обличаме ги с нови Арехи, с туй показваме нашето възкресение, наливаме върху им масло, с туй показваме нашето кръщение, калиме ги с тамян, с той показваме тъмнотата на този свят, палиме свещи, с туй показваме светлината на онзи свят, полагаме ги срещу Изток, с туй показваме как ще оживеят и ще отидат къАе изток за страшният сьА" 11 (Vrachanski, 1856: p. 242). Така мас^освета наА покойник е

11 Цит по: Врачански, св. Софрроний. Поучително евангелие За всичките недели през годината за господските и богородичните празници и за по-големите светии. Нови СаА., 1856 г. с. 242; [Revival Books / ВъзрожАенски книги, http://digilib.nalis.bg/xmlvi/handle/nls/86, (Last view: 01.09.2019)]; 
отслужван в продьлжение на четири века, като съставът му е бил установен още от самото начало.

Чинопоследованието може да се определи, че е било установено от времето когато Йосиор и Николим помазали Христос със смес от смирна и алой преди Аа го положат в гроба (Йоан 19: 39-40). За това събитие св. Содрроний пише слеАното: „Това змирно (смирна), Аето помазали Христа, толко е прилепително, щото каквото се залепи за него, не може вече $а$ а се отлепи. Туй всичкото било според божието смотрение, щото като възкрьсне Христос, $л а$ не кажат евреите, че го откралнаха апостолите..." (Vrachanski, 1856: р. 68). Така връзката межлу помазване на тялото и балсамирането му в Аревни времена са изконни свещенодействия получили своето поприще в маслосвет наА покойник. С Аействието балсамиране от старозаветната епоха на Яков (Бит 50:2) и Йосифо (Бит. 50:26) се предвещава помазването на Христовото тяло, с което можем да означим, че старозаветните праотци са предобрази на Иисус. Това са събитията, които са станали основа за установяване на обрела помазване нал покойник. Останалите Аействия повлияли за съставянето на чина се крият в апостолските и евангелските четива, произнасяни по време на неговото служене и съхранени в препис № 64 .

\section{Интернет ресурси / Internet Sources:}

Canonization / Канонизация [http://www.pravenc.ru/text/1470233.html, (Last view: 01.09.2019)]

Wreath / Венчик [http://www.pravenc.ru/text/150357.html, (Last view: 01.09.2019)]

Prayers for the dead - Saint Tsar Boris Church / Молитвени послеАования за покойниците - Храм Свети цар Борис [https://sveticarboris.net/2011/02/13/момитвени-послеАования-за-покойници, (Last view: 01.09.2019)]

Revival Books / ВъзрожАенски книги [http://digilib.nalis.bg/xmlui/handle/nls/86, (Last view: 01.09.2019)] 


\section{AИTEPATYPA / REFERENCES}

Avxentii, archim. (2006). Liturgy. Plovdiv, 2006 (In Bulgarian) / [Авксентий, архим. Аитургика. ПАовАив, 2006 г.]

Kodov, Hr. (1969). List of Slavic manuscripts in the Library of BAS. S., 1969, V. V (In Bulgarian) / [КоАов, Хр. Опис на славянските рькописи в библиотеката на БАН. C., 1969г., Т. V]

Milosevic, Nenad, (2011). Prayer for the dead. Belgrade, 2011 (In Bulgarian) / [Милошевич, НенаА. Молитвени последования за покойниците. БелграА, 2011 г.]

Ordinary book, (2002). Ordinary book, Ed. St. Synod,. S. 2002 (In Bulgarian) / [Требник. Синол. изАателство. С. 2002]

Petkanova, Donka, (2011). Funeral customs and funeral texts according to literary sources. In: Studia mediaevalia Slavica et Byzantina Death and burial in the Judeo-Christian tradition. S. 2011, (In Bulgarian) / [Петканова, Аонка. Погребалните обичаи и погребални текстове спореА книжовни извори. В: Studia mediaevalia Slavica et Byzantina Смьртта и погребението в юлео християнската традиция. С. 2011 г.,]

Popov, Iv. (1980). Grievances (complaints of the dead). In: SBU, S., 1890. b. 2. (In Bulgarian) / [Попов, Ив. Тжжачки (оплаквания на мъртъвци). В: СбНУ, С., 1890 г. KH. 2.]

Shivarov, protopr., Nikolai, (1992). Biblical Archeology. S., 1992 (In Bulgarian) / [Шиваров, протопр., Николай. Библейска археология. С., 1992 г.]

Shivarov, protopr., Nikolai, (2011). Bible mournful songs in their ancient Middle Eastern context. In: Studia mediaevalia Slavica et Byzantina Death and burial in the Judeo-Christian tradition. S. 2011 (In Bulgarian) / [Шиваров, протопр., Николай. Библейските плачевни песни в техния Аревен близкоизточен контекст. В: Studia mediaevalia Slavica et Byzantina Смьртта и погребението в юлео - християнската традиция. С. 2011 г.,]

Tsankov, St., candlestick, protodiac.; Stefanov, Iv.; Tsanev, P. (1913). The rules of the Holy Orthodox Church with their interpretations. S. 1913 (In Bulgarian) / [Цанков, Ст., свещ., протодиак. Ив. Стефанов, П. Цанев. Правилата на св. православна цьрква С тьлкованията имъ. С. 1913 г.]

Vrachanski, St. Sophronius, (1856). A gospel of instruction for all the Sundays of the year for the feasts of the Lord and the Virgin, and for the greater saints. Novi Sad, 1856 (In Bulgarian) / [Врачански, Св. Софрроний. Поучително евангелие За всичките неАели през голината за господските и богородичните празници и за по-големите светии. Нови СаА., 1856 г.] 


\section{КУАТУРНО-ИСТОРИЧЕСКО НАСАЕАСТВО: \\ ОПАЗВАНЕ, ПРЕАСТАВЯНЕ, АИГИТААИЗАЦИЯ}

CULTURAL AND

HISTORICAL

HERITAGE

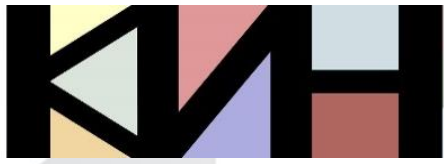

PRESERVATION PRESENTATION

DIGITIZATION
Материалите в сборника са обект на авторско право. Разрешава се безвъзмезАното ползване на техни електронни/ хартиени копия само за лична употреба или обучение, при пь^но цитиране на текущата страница и слеА писмена декларация от цитиращия за Аипса на търговски намерения. За копиране пол Аруга фрорма, препубликуване или публикуване на сървъри се изисква писмено разрешение и/или заплащане.

() Авторски колектив, 2019 Технически реАактори: Николай Ноев Калина Сотирова-Вълкова Ка^оян Николов

\section{Editors}

Galina Bogdanova Vanya Mateeva

This work is subject to copyright. Open and free of charge use of digital/hard copies of publications is granted only for personal or educational use, with full citation of the current page, and after written declaration of the quoting side for not-commercial Intention. For any other reproducing types, republishing, photocopying, recording, or any other storage retrieval system/ server written permission and/or fee is required.

(C) Authors` Group, 2019

Technical editors:

Nikolay Noev

Kalina Sotirova-Valkova

Kaloyan Nikolov

Научна поредица: том 5, брой 2 (7)/2019

Science series: vol. 5 , issue $2(7) / 2019$

www.math.bas.bg/vt/kin

ISSN: 2367-8038 